\title{
SECULAR AND CHRISTIAN LEADERSHIP IN CORINTH
}

\author{
Andrew D. Clarke
}

\section{Introduction}

The dissertation traces the influences of first century, Corinthian, secular leadership on local church leadership as reflected in 1 Corinthians 1-6 and then shows how Paul modifies the Christian understanding of church leadership. ${ }^{1}$

In the past the study of the nature and development of local leadership in the New Testament churches has often focused on the process of institutionalisation through the first two centuries and the antithesis between those churches emphasising the Spirit and charisma and those, assumed later, with formal structures and offices.

Many such studies have either been too narrowly constructed on the theological ideals of the Pauline material or too strongly dictated by modern social theory. A more appropriate method is to assess the New Testament material in the light of its social and historical background.

By comparing secular leadership in first century Corinthian society with leadership in the Corinthian church, it has been argued that one of Paul's major concerns with the church in Corinth is the extent to which significant members in the church were employing secular categories and perceptions of leadership in the Christian community.

\section{Graeco-Roman Leadership Profiles}

The nature and practices of Graeco-Roman leaders can be determined both from literary as well as Corinthian epigraphic and numismatic sources. They show that social élites jostled for position and popularity in Graeco-Roman city life and status; patronage and benefaction, political enmity and oratory were crucial to a successful profile of secular, political leadership.

${ }^{1}$ Andrew D. Clarke, Secular and Christian Leadership in Corinth: $a$ Socio-historical and Exegetical Study of 1 Corinthians 1-6 (Unpublished PhD Thesis, Cambridge University 1991). 
Wealth and property in the Graeco-Roman world formed the basis of the society's structure and personal, social advancement. Leadership in the Roman colony of Corinth was expensive and therefore élitist. It was thus a necessary prerequisite to be among the wise, well-born and powerful.

A leader was one who was respected, had standing and honour, was eloquent in the assembly and had a number of influential friends and clients. Furthermore he recognised and affirmed the social barriers of class and status.

\section{Secular Leadership in 1 Corinthians 1-6}

Within the Christian community there were some from this Corinthian social élite. This is seen at a number of points:

Firstly, the reference in 1 Corinthians 1.26 to the

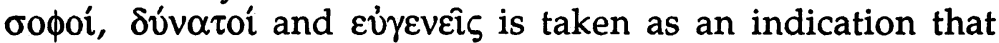
there were at least some members of the congregation who enjoyed the privileges of the Corinthian social élite.

Secondly, the figure of Erastus, termed oikovó $\mu$ os $\tau$ ins $\pi$ ó $\lambda \varepsilon \omega_{S}$ in Romans 16.23 , offers the possibility of an identified civic leader being a significant member of the Corinthian church. This identification remains tantalisingly unproven but it does not exclude the probability that amongst some of the named members of the congregation there were those who clearly had some of the privileges of the wealthy, including property and the means of travelling.

Thirdly, it is then not surprising that Paul in 1 Corinthians 1-6 draws repetitive contrasts between the ways of God and the ways of secular society concerning leadership.

Fourthly, Paul contends that secular wisdom is being defended by some in the church. He is aware of the tension which exists in the Corinthian church with its preoccupation with the characteristics of secular, high society and in his letter specifically addresses those within the church who demonstrate this tension.

Fifthly, the so-called 'parties' in Corinth are strongly reminiscent of the factions which developed between rival leading figures in civic life. Such tensions centred not on policy or personal manifesto, but on patronage. Paul's concern is not with the respective theologies of different groups, but solely that the Corinthians were aligning themselves with these specific personalities in a personality-cult. 
Sixthly, boasting was peculiarly prominent in the Corinthian church and yet also typical of first-century high society. In addition their boasting was over symbols of status such as wisdom, influence and family pedigree.

Seventhly, it is argued that secular political influences were an explanation for the discord within the community at Corinth. Just as amicitia and inimicitiae were important in the political forum, so it may have become important also in a church so strongly influenced by its surrounding society.

Eighthly, the wisdom which is so highly regarded by those in the church is termed by Paul to be the wisdom of the world. It is unnecessary to look further than this consistent background of secular influence to find an understanding of the nature of the Corinthian $\sigma o \phi i \alpha$.

Ninthly, evidence is shown which demonstrates that the luxurious lifestyle of secular leaders was widespread and publicly justified by them. In 1 Corinthians $6.12 \mathrm{ff}$. there appears to be a similar readiness to justify the indulgence of the senses. It is not necessary to assume that the Corinthian slogan $\pi \alpha \dot{v} \tau \alpha \mu$ or $\varepsilon^{\prime} \xi \sigma \tau \nu$ suggests a libertarianism which has a theological justification.

Two instances documented in 1 Corinthians demonstrate further those practices in the church which mirrored secular society. Firstly, in 1 Corinthians $6.1-8$ Christians from élite society were taking their fellow brothers to the secular law courts. The Graeco-Roman world of legal suits was a world where the socially inferior were prejudiced against both in legal procedure and legal privilege. The Roman law courts provided a forum where the successful litigant could greatly enhance his own reputation, whilst at the same time injuring that of his opponent. It may be assumed that plaintiffs were almost entirely people of high social status. With these aspects of Roman litigation in mind, it may be assumed that to have overcome all the obstacles to litigation, it must be concluded that the Christian brothers were of senior status. Secondly, there is the strong likelihood that these legal proceedings were being used by members of the Christian community to establish their own standing and reputation at the cost of another's. Paul strongly argues that those in the community should not resort to the secular courts and its practices. Rather, such matters should be dealt with in the community, where even the 
'despised' of society are qualified-'wise' enough-to handle such disputes.

Secondly, the congregation's toleration of gross sexual immorality within the church in 1 Corinthians 5 may have arisen for reasons of expediency. The Corinthians were 'puffed up' in 1 Corinthians 5.2 despite the immorality rather than because of it. This provides another instance where the church was simply 'taking pride in a man', for example an influential leading figure. If the guilty brother were a significant patron of the church then it would have been certainly difficult, perhaps impossible, to confront him on the matter of incest. Paul, however, took the church to task because their assessment of the status of the incestuous man-their 'pride' in him-had caused them to overlook their need to confront him on the matter of sexual immorality.

\section{Paul's View of Leadership in 1 Corinthians 1-6}

In the light of this intrusion of secular perceptions of leadership into the Corinthian church, Paul defines for the church some Christian principles of leadership. His own example demonstrates an avoidance of persuasive oratory and secular boasting, and a refusal to give particular esteem to certain Christians on the grounds of their secular status.

Paul's criticism arises from his identification of aspects of secular leadership in the church. This consistently emerges throughout the early chapters of the epistle. In addition, Paul constructed for the Corinthians different parameters of leadership. He deliberately focused not on status, but on task; the terminology used was specifically that of function. This is most clearly be seen in his use of agricultural and artisan language.

Paul also makes specific reference to individuals who are seen as examples of good Christian leadership based on their commitment to service and not status. Stephanus in 1 Corinthians $16.15-18$ is notable in this respect.

This analysis of the leadership in the Corinthian church produces a picture consistent not only with the text of 1 Corinthians but also with the social historical background of secular Roman leadership. It may be felt, therefore, that any historical study of the Corinthian church which does not take on board the possible impact of its surrounding society is liable to produce limited results. 